\title{
Brain Morphophysiology of Africanized Bee Apis mellifera Exposed to Sublethal Doses of Imidacloprid
}

\author{
Caroline de Almeida Rossi - Thaisa Cristina Roat • \\ Daiana Antonia Tavares · Priscila Cintra-Socolowski • \\ Osmar Malaspina
}

Received: 12 December 2012/ Accepted: 3 March 2013

(c) Springer Science+Business Media New York 2013

\begin{abstract}
Several synthetic substances are used in agricultural areas to combat insect pests; however, the indiscriminate use of these products may affect nontarget insects, such as bees. In Brazil, one of the most widely used insecticides is imidacloprid, which targets the nervous system of insects. Therefore, the aim of this study was to evaluate the effects of chronic exposure to sublethal doses of imidacloprid on the brain of the Africanized Apis mellifera. The organs of both control bees and bees exposed to insecticide were subjected to morphological, histochemical and immunocytochemical analysis after exposure to imidacloprid, respectively, for $1,3,5,7$, and 10 days. In mushroom bodies of bees exposed to imidacloprid concentrations of $\mathrm{LD}_{50 / 10}$ and in optic lobes of bees exposed to imidacloprid concentrations of $\mathrm{LD}_{50 / 10}$, $\mathrm{LD}_{50 / 100}$, and $\mathrm{LD}_{50 / 50}$, we observed the presence of condensed cells. The Feulgen reaction revealed the presence of some cells with pyknotic nuclei, whereas Xylidine Ponceau stain revealed strongly stained cells. These characteristics can indicate the occurrence of cell death. Furthermore, cells in mushroom bodies of bees exposed to imidacloprid concentrations of $\mathrm{LD}_{50 / 10}$ appeared to be swollen. Cell death was confirmed by immunocytochemical technique. Therefore, it was concluded that sublethal doses of imidacloprid have cytotoxic effects on exposed bee brains and that optic lobes are more sensitive to the insecticide than other regions of the brain.
\end{abstract}

C. de Almeida Rossi · T. C. Roat ( $)$ · D. A. Tavares .

P. Cintra-Socolowski - O. Malaspina

Departamento de Biologia, Centro de Estudos de Insetos Sociais, Instituto de Biociências de Rio Claro, UNESP-Universidade

Estadual Paulista, Av. 24A, 1515, Bela Vista, Rio Claro,

SP 13500-900, Brazil

e-mail: thaisaroat@yahoo.com.br
The value of insect pollination has been estimated at 212 billion dollars, representing approximately $9.5 \%$ of the total value of agronomy production (Gallai et al. 2009). Bees are among the main pollinators, being responsible for $35 \%$ of food crop pollination by insects (Klein et al. 2007; Willians 1995).

In some places, including Europe and the United States, the loss of bee colonies is a large problem for beekeepers. The loss of bee colonies is known as "colony collapse disorder" (CCD). Although the causes of CCD are unclear, it has been speculated that the interaction of several factors, including bacterial diseases and mite infestations, may affect the health of the colony. In addition, the chemical intoxication of bees is of major concern. Due to deforestation of their natural habitats, bees have increased their foraging activities in agricultural areas. Modern agriculture depends increasingly on the use of chemicals to control weeds, fungi, and arthropod pests in cultivated areas. As a consequence of foraging in agricultural areas, bees are increasingly being exposed to these chemicals (Croft 1990; Thompson 2003; Malaspina and Silva-Zacarin 2006; Desneux et al. 2007).

Neonicotinoid insecticides are the most commonly used on Brazilian crops. Imidacloprid is a neonicotinoid that is applied mainly to sugar cane, coffee, citrus, and cotton crops (Brasil 2001). This insecticide acts by binding to and inhibiting the function of nicotinic acetylcholine receptors in insects (Buckingham et al. 1997). These receptors are found in many regions of bee brain, including areas involved in learning and memory (Bicker 1999).

Medrzycki et al. (2003) evaluated the effect of sublethal doses of imidacloprid on the behavior of the honeybee ( $A$. mellifera). At both imidacloprid concentrations tested (100 and $500 \mathrm{ppb}$ ), they observed a decrease in bee mobility and communication, which can compromise the social behavior 
of these insects. Another study evaluated the effects of imidacloprid at concentrations of $0.5 \mathrm{mg} / \mathrm{L}$ and $5 \mu \mathrm{g} / \mathrm{L}$. The results of this study showed that imidacloprid is toxic to bees, changing their driving frequency during pollen foraging and altering the number of operculated cells in the hive (Faucon et al. 2005).

Many studies have been conducted to evaluate the toxicity of imidacloprid in bees. Small, sublethal doses of insecticides may not directly cause the death of bees but instead may induce changes in bee behavior. Some effects include a decrease in foraging activity or disorientation, which can affect the entire colony. The aforementioned changes have been observed in some studies that evaluated the acute toxicity of imidacloprid (Bortolotti et al. 2003; Medrzycki et al. 2003; Decourtye et al. 2004; Schmuck 2004). The objective of this study was to evaluate the effects of sublethal doses of imidacloprid on brains of workers of Africanized Apis mellifera.

\section{Materials and Methods}

\section{Chemicals}

The analytical reference standard of imidacloprid $(92.5 \%$ purity) was obtained from Bayer CropScience (Brazil). Sodium chloride $(\mathrm{NaCl})$, dibasic sodium phosphate $\left(\mathrm{Na}_{2} \mathrm{HPO}_{4}\right)$, monobasic potassium phosphate $\left(\mathrm{KH}_{2} \mathrm{PO}_{4}\right)$, paraformaldehyde, ethanol, hematoxylin, eosin, Xylidine Ponceau, periodic acid, Schiff's reagent, hydrochloric acid, xylene, and polylysine were obtained from Sigma-Aldrich (Brazil). The terminal deoxynucleotidyl transferase-mediated biotinylated UTP nick end-labeling (TUNEL) reaction kit (ISCDDK in situ Cell Death Detection Kit) was obtained from Roche Molecular Biochemicals. The historesin embedding kit was purchased from Leica Microsystems (Germany). The paraffin (Histosec) was obtained from Merck (Brazil).

\section{Honeybee Collection}

Newly emerged adult bees of Africanized A. mellifera were collected directly from combs in the apiary of the Institute of Biosciences of Universidade Estadual Paulista, Campus of Rio Claro, São Paulo State, Brazil. We verified the health and physiological status of the colony according to the guidelines of the Organisation for Economic Co-Operation and Development (OECD 1998) for testing chemicals in bees.

\section{Oral Acute Toxicity}

We calculated the lethal dose $50\left(\mathrm{LD}_{50}\right)$ of imidacloprid to Africanized honey bees using an ingestion bioassay. Newly emerged bees were placed in disposable cages (10 bees/ cage) tat had been previously lined with filter paper. Three replicates of each dose and control group were performed. The experiments were conducted in an environmental biochemical oxygen demand (BOD) chamber with temperatures held at $32 \pm 1{ }^{\circ} \mathrm{C}$ and relative humidity of $70 \%$. The treated and control groups received food and water ad libitum.

The bees were starved for $\leq 2 \mathrm{~h}$ and then exposed to a range of doses of imidacloprid dispersed in sucrose solution in water $(50 \% \mathrm{w} / \mathrm{v})$. The stock solution of imidacloprid was made in acetone $100 \%(\mathrm{v} / \mathrm{v})$ and then diluted in the sucrose diet. Five doses of imidacloprid were prepared in a geometric series with final range from 80 to $100 \mathrm{\eta g}$ imidacloprid $/ \mu \mathrm{L}$ diet. For each treatment, a dilution was made to obtain the desired concentration in $1,000 \mu \mathrm{L}$ of sucrose solution. The control group was fed with the same diet free of the test substance. Two separate control groups were used: a sucrose solution in water and a sucrose solution with the solvent (acetone) at the concentration used in dosing solutions.

Once consumed (usually within 3-4 h), the feeder was removed from the cage and replaced with one containing sucrose solution alone. The sucrose solutions were then provided ad libitum. Subsequently, mortality was recorded at $4 \mathrm{~h}$ after start of the test and thereafter at 24 and $48 \mathrm{~h}$ (i.e., after given dose). Bees from the control groups did not reach a $10 \%$ mortality rate for the validation test (OECD 1998).

Data were analyzed using Probit regression by plotting the dose-response curves for each observation period. Corrections for control mortality were made using Abbott's method (OECD 1998).

\section{Honeybee Intoxication Assay}

Bees were placed in disposable cages (10 bees/cage) lined with filter paper. Three replicate experiments were performed for each dose of imidacloprid or control treatment. The experiments were conducted in an environmental BOD chamber at a temperature of $32 \pm 1{ }^{\circ} \mathrm{C}$ and relative humidity of $70 \%$. The experimental and control groups received the same water supply consisting of cotton soaked in water and food $(10 \mu \mathrm{L} / \mathrm{bee})$. There were two control groups: (1) bees not exposed to solvent, which were fed a diet consisting of sucrose and water $50 \%(\mathrm{w} / \mathrm{v})$; and (2) bees exposed to solvent, which were fed the same diet supplemented with acetone $1 \%(\mathrm{v} / \mathrm{v})$ (the solvent used in the pesticide solution).

The sublethal doses used in this study were calculated using the $\mathrm{LD}_{50}$ obtained according to the procedure described in Oral Acute Toxicity. A stock solution of imidacloprid was prepared, dissolved in acetone, and 
Table 1 Summary of morphological, histochemical, and immunohistochemical analyses on mushroom bodies of A. meliffera exposed to sublethal doses of imidacloprid

\begin{tabular}{|c|c|c|c|c|c|c|}
\hline \multirow[t]{2}{*}{ Treatment } & \multirow[t]{2}{*}{ Days } & \multicolumn{2}{|c|}{ H\&E staining } & \multirow{2}{*}{$\begin{array}{l}\text { Fuelgen reaction } \\
\text { Nuclei with compaction } \\
\text { of chromatin }\end{array}$} & \multirow{2}{*}{$\begin{array}{l}\text { Xylidine Ponceau staining } \\
\text { Increase in the intensity } \\
\text { of staining }\end{array}$} & \multirow{2}{*}{$\begin{array}{l}\text { TUNEL reaction } \\
\text { Nuclei } \\
\text { positive }\end{array}$} \\
\hline & & $\begin{array}{l}\text { Condensed } \\
\text { cells }\end{array}$ & $\begin{array}{l}\text { Cells with swollen } \\
\text { appearance }\end{array}$ & & & \\
\hline \multirow[t]{5}{*}{ Control without solvent } & 1 & - & - & - & - & - \\
\hline & 3 & - & - & - & - & - \\
\hline & 5 & - & - & - & - & - \\
\hline & 7 & - & - & - & - & - \\
\hline & 10 & - & - & - & - & - \\
\hline \multirow[t]{5}{*}{ Control with solvent } & 1 & - & - & - & - & - \\
\hline & 3 & - & - & - & - & - \\
\hline & 5 & - & - & - & - & - \\
\hline & 7 & - & - & - & - & - \\
\hline & 10 & - & - & - & - & - \\
\hline \multirow[t]{5}{*}{$\mathrm{LD}_{50 / 100}$} & 1 & - & - & - & - & - \\
\hline & 3 & - & - & - & - & - \\
\hline & 5 & - & - & - & - & - \\
\hline & 7 & - & - & - & - & - \\
\hline & 10 & - & - & - & - & - \\
\hline \multirow[t]{5}{*}{$\mathrm{LD}_{50} / 50$} & 1 & - & - & - & - & - \\
\hline & 3 & - & - & - & - & - \\
\hline & 5 & - & - & - & - & - \\
\hline & 7 & - & - & - & - & - \\
\hline & 10 & - & - & - & - & - \\
\hline \multirow[t]{5}{*}{$\mathrm{LD}_{50} / 10$} & 1 & - & - & - & - & + \\
\hline & 3 & + & - & + & + & + \\
\hline & 5 & + & - & + & + & + \\
\hline & 7 & + & - & + & + & + \\
\hline & 10 & + & + & + & + & + \\
\hline
\end{tabular}

+ presence of alteration, ++ alteration moderately present, +++ alteration extremely present, - alteration absent, $L_{50}$ lethal dose

mixed with sucrose solution. Three dilutions of this imidacloprid stock solution were made to yield final concentrations of $\mathrm{LD}_{50 / 100}, \quad \mathrm{LD}_{50 / 50}$, and $\mathrm{LD}_{50 / 10}$. The experimental groups were fed the contaminated diet consisting of these sublethal doses. The periods of exposure to the insecticide were $1,3,5,7$, and 10 days for each group. Six bees were used per treatment group for the assay.

\section{Morphological and Histochemical Analysis}

To extract the brain, dissection was carried out on bees in Petri dishes containing saline solution $\left(20 \mathrm{mM} \mathrm{Na}_{2} \mathrm{HPO}_{4} /\right.$ $\mathrm{KH}_{2} \mathrm{PO}_{4}[\mathrm{pH}$ 7.4] and $130 \mathrm{mM} \mathrm{NaCl}$ ) under a Zeiss stereomicroscope using dissecting forceps and microscissors. The organs were fixed in paraformaldehyde $4 \%(\mathrm{w} /$ v) in phosphate-buffered saline [0.1 M (pH 7.4)]. Subsequently, the material was dehydrated in a series of ethanol solutions at $4{ }^{\circ} \mathrm{C}$ of the following concentrations: 15,30 ,
50, 70, 85, 90, 95, and $100 \%(\mathrm{v} / \mathrm{v})$. Each dehydration step lasted for $2 \mathrm{~h}$. After dehydration, the material was incubated in embedding historesin for 3 days. Subsequently, $7-\mu \mathrm{m}$ sections were cut using a Leica Microtome (Germany).

Some sections of brain were stained with hematoxylin and eosin (H\&E) for morphological analysis. Other brain sections were stained with Xylidine Ponceau to detect total protein (Junqueira and Junqueira 1983) or were subjected to Feulgen reaction (counterstained with Fast Green) to determine the level of chromatin compaction (Feulgen and Rossenbeck 1924).

Finally, sections were examined under a light microscope (Olympus BX51; Olympus America). Photomicrographs were obtained using a digital camera (Olympus DP71) that was fitted to the microscope and coupled to a Dell computer. DP Controller software (Olympus America) was used for image acquisition. 
Immunocytochemical Detection of DNA

Fragmentation by Endonucleases

Brains were dissected and fixed as described previously. After dehydration in a series of ethanol solutions, organs were diaphanized in xylene and embedded in paraffin (Histosec). Sections of $8-\mu \mathrm{m}$ thickness were transferred to histological slides that had been cleaned and treated with
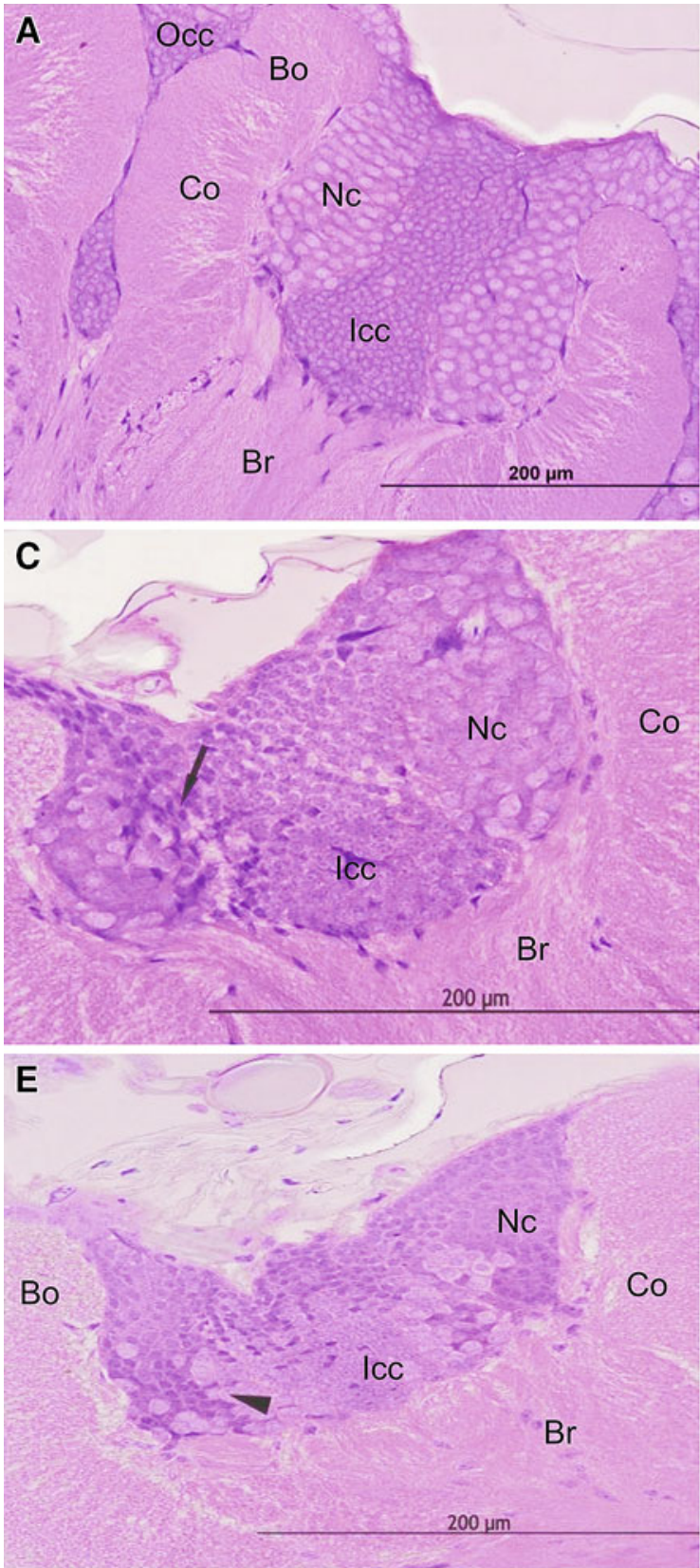

Fig. 1 Images of H\&E-stained mushroom bodies of newly emerged worker bees of Africanized A. mellifera with or without exposure to imidacloprid. a, b General and magnified views of mushroom bodies from the control group with 7 days showing no morphological alterations. c, d General and magnified views of mushroom bodies from bees with exposure to an imidacloprid concentration of $\mathrm{LD}_{50 / 10}$ polylysine. The Histosec wax was removed with several xylene washes before sections were rehydrated and subjected to TUNEL reaction (using the ISCDDK in situ Cell Death Detection Kit) according to the manufacturer's instructions. Negative and positive controls were included for the TUNEL reaction experiment. After incubation, the slides were examined for the presence of fluoresceinlabeled $3^{\prime}-\mathrm{OH}$ ends of fragmented DNA. Fluorescent
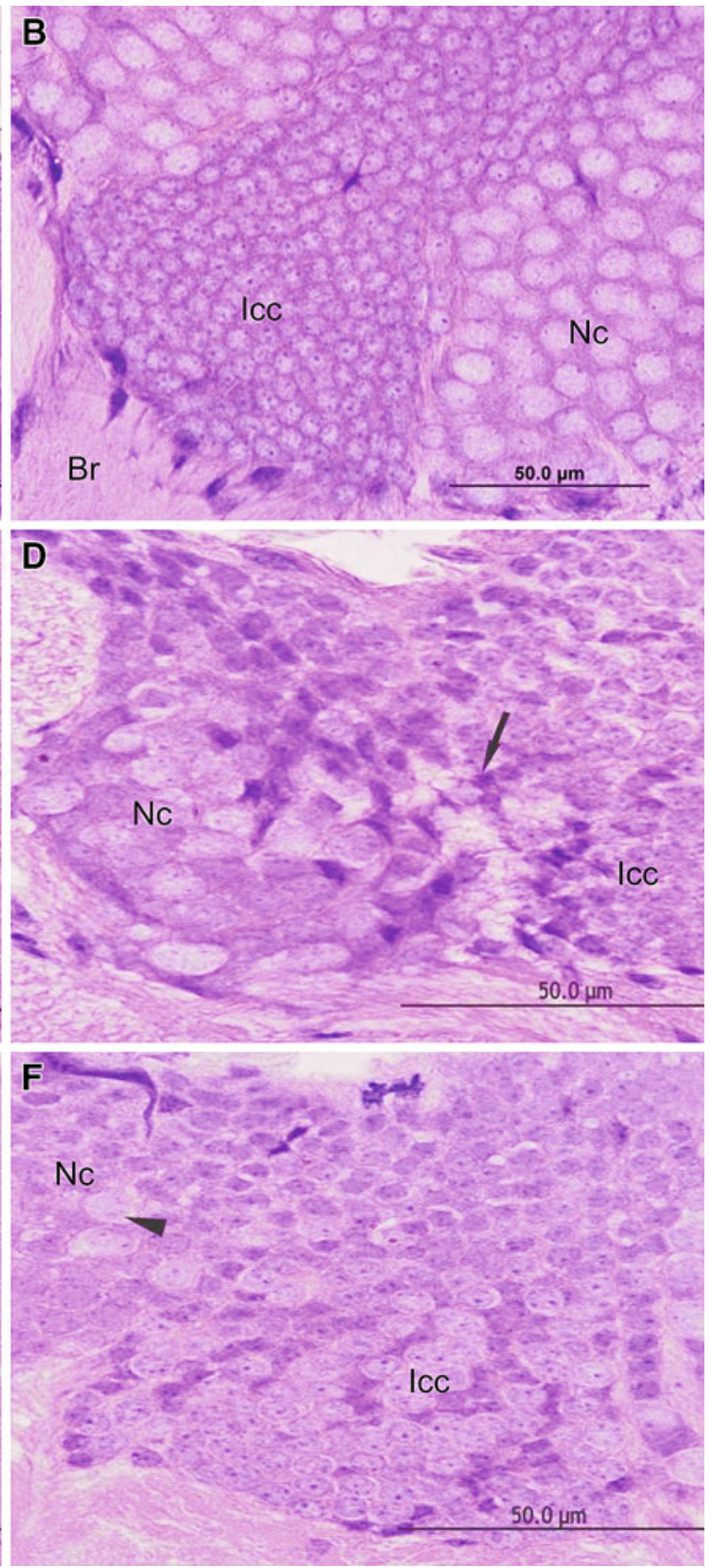

for 7 days showing the presence of intensely stained cells (arrow). e, f General and magnified views of mushroom bodies of bees with exposure to an imidacloprid concentration of $\mathrm{LD}_{50 / 10}$ for 10 days. Note the presence of cells with a swollen appearance (arrowhead in f). $B r$ basal ring, $B o$ border, $C o$ collar, $O c c$ outer compact cells, $I c c$ inner compact cells, $N c$ noncompact cells 
images were captured using an Olympus BX-51 fluorescence microscope (Olympus America) at a wavelength of $450-500 \mathrm{~nm}$.

\section{Results}

\section{Acute Toxicity Assay}

The $\mathrm{LD}_{50}$ of imidacloprid to A. mellifera was established at $80.9 \eta \mathrm{g} /$ bee $\left(\chi^{2}=56.778\right.$, slope $\left.=2.781 \pm 1.757\right)$. From this value, we calculated the sublethal doses equivalent to $\mathrm{LD}_{50} / 100$ (0.809 $\left.\eta \mathrm{g} / \mathrm{bee}\right), \mathrm{LD}_{50} / 50$ (1.618 $\left.\eta \mathrm{g} / \mathrm{bee}\right)$, and $\mathrm{LD}_{50} / 10(8.09 \eta \mathrm{g} / \mathrm{bee})$ to be used in other experiments.

\section{Morphological and Histochemical Analysis}

\section{Mushroom Bodies}

The results obtained from mushroom bodies of bees exposed to imidacloprid are listed in Table 1. Morphological and histochemical alterations in mushroom bodies were not observed in the groups of bees exposed to imidacloprid at concentrations of $\mathrm{LD}_{50 / 100}$ or $\mathrm{LD}_{50 / 50}$ and those in he control groups (Fig. 1a, b). However, the presence of condensed cells was detected in the group of bees exposed to imidacloprid for $\geq 3$ days at a concentration of $\mathrm{LD}_{50 / 10}$ using $\mathrm{H} \& \mathrm{E}$ staining technique (Fig. 1c, d). In the same treatment group $\left(\mathrm{LD}_{50 / 10}\right.$, bees exposed for $\geq 3$ days), Feulgen reaction revealed the presence of strongly stained nuclei in some cells, thus indicating the occurrence of chromatin condensation (Fig. 2c, d). Staining with Xylidine Ponceau revealed strongly stained cells, which may indicate the presence of cell compaction (Fig. 2g, h). In control groups, nuclei were weakly stained by Feulgen reaction (Fig. 2a, b), and cells were weakly stained after Xylidine Ponceau staining (Figs. 2e, f).

The presence of strongly stained nuclei visualized during histochemical and morphological analysis indicates the occurrence of cell death in Kenyon cells of exposed bees. TUNEL assay revealed the presence of positive nuclei in Kenyon cells of bees exposed to imidacloprid for all periods at a concentration of $\mathrm{LD}_{50 / 10}$ (Fig. 4b). Positive nuclei were not observed in the control group using this technique (Fig. 4a).

In addition to intense $\mathrm{H} \& \mathrm{E}$ staining of mushroom bodies observed after imidacloprid exposure, morphological alterations were observed in some Kenyon cells in mushroom bodies of bees exposed to an imidacloprid concentration of $\mathrm{LD}_{50 / 10}$ for 10 days (Figs. 1e, f). Kenyon cells in this treatment group exhibited less staining and were greater in size, indicating the occurrence of cell swelling.

\section{Optic Lobes}

Table 2 lists the results obtained from optic lobes of control and imidacloprid-treated bees. H\&E staining revealed the presence of condensed cells in optic lobes of bees exposed to imidacloprid at a concentration of $\mathrm{LD}_{50 / 10}$ for all exposure times tested and in bees exposed to concentrations of $\mathrm{LD}_{50 / 100}$ and $\mathrm{LD}_{50 / 50}$, for 5,7 , or 10 days. The presence of condensed cells in these treatment groups was indicated by intense cell staining and decreased cell volume (Fig. 3b). At the same imidacloprid concentrations and exposure times, Feulgen reaction produced intensely stained nuclei, thus indicating the presence of chromatin compaction (Fig. 3d). In addition, cells were intensely stained by Xylidine Ponceau (Fig. 3f), which may indicate increased protein synthesis or cell compaction. No significant alterations in H\&E staining (Fig. 3a), Feulgen reaction staining (Fig. 3c), and Xylidine Ponceau staining (Fig. 3e) were observed in optic lobes of control bees.

Immunocytochemical analysis of optic lobes using TUNEL assay found positive nuclei in all groups of imidacloprid-treated bees at all exposure times, thus indicating that they were undergoing cell death (Fig. 4d). Positive nuclei were not detected in the control groups (Fig. 4c).

\section{Discussion}

Our results establish the $\mathrm{LD}_{50}$ of $80.9 \eta \mathrm{g} / \mathrm{bee}$ for the insecticide imidacloprid in Africanized honeybees, thus showing this insecticide is harmful to these bees. This value is close to the one found by Nauen et al. (2001) in European bees, which reported a $48-\mathrm{h}$ oral $\mathrm{LD}_{50}$ of imidacloprid between 41 and $81 \mathrm{\eta g} / \mathrm{bee}$. The small variation found is the result of differences in both the conditions of the experiment and the subspecies of A. mellifera used. Other factors that may contribute to this variation include the age of bees (Guez et al. 2001), the colony used (Suchail et al. 2001) and the season (Decourtye et al. 2003).

There were detectable morphological, histochemical, and immunocytochemical alterations in mushroom bodies and optic lobes of bees exposed to imidacloprid compared with the control groups. Morphological alterations observed in mushroom bodies and optic lobes of imidacloprid-treated bees included more intense H\&E staining indicating the presence of condensed cells. Chromatin condensation in the nuclei of cells from these brain structures was also evident when these tissues were subjected to Feulgen reaction.

Cell condensation may indicate the occurrence of cell death by apoptosis (Bowen et al. 1998). The presence of chromatin compaction in nuclei of cells can indicate that these cells are in a state of low transcriptional activity, 


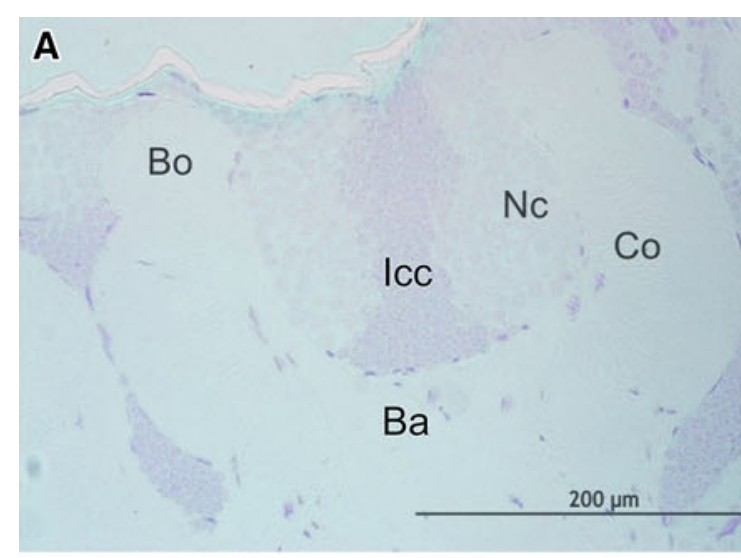

\section{B}

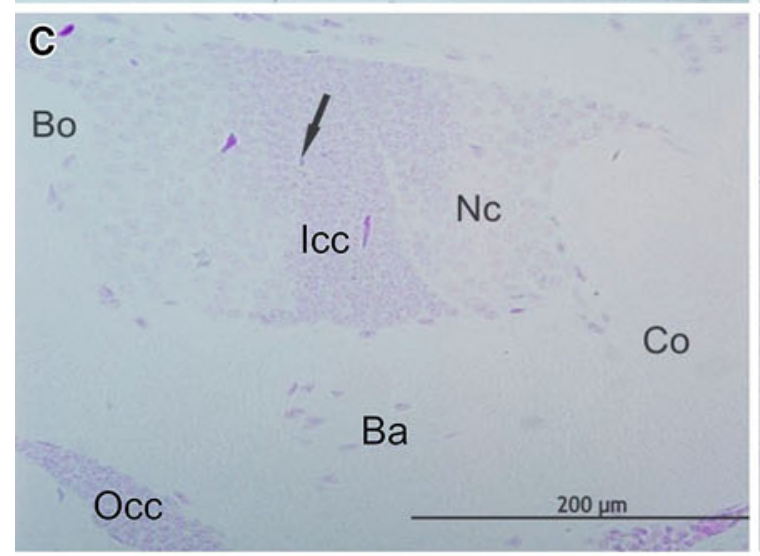

\section{D}

Nc

Nc
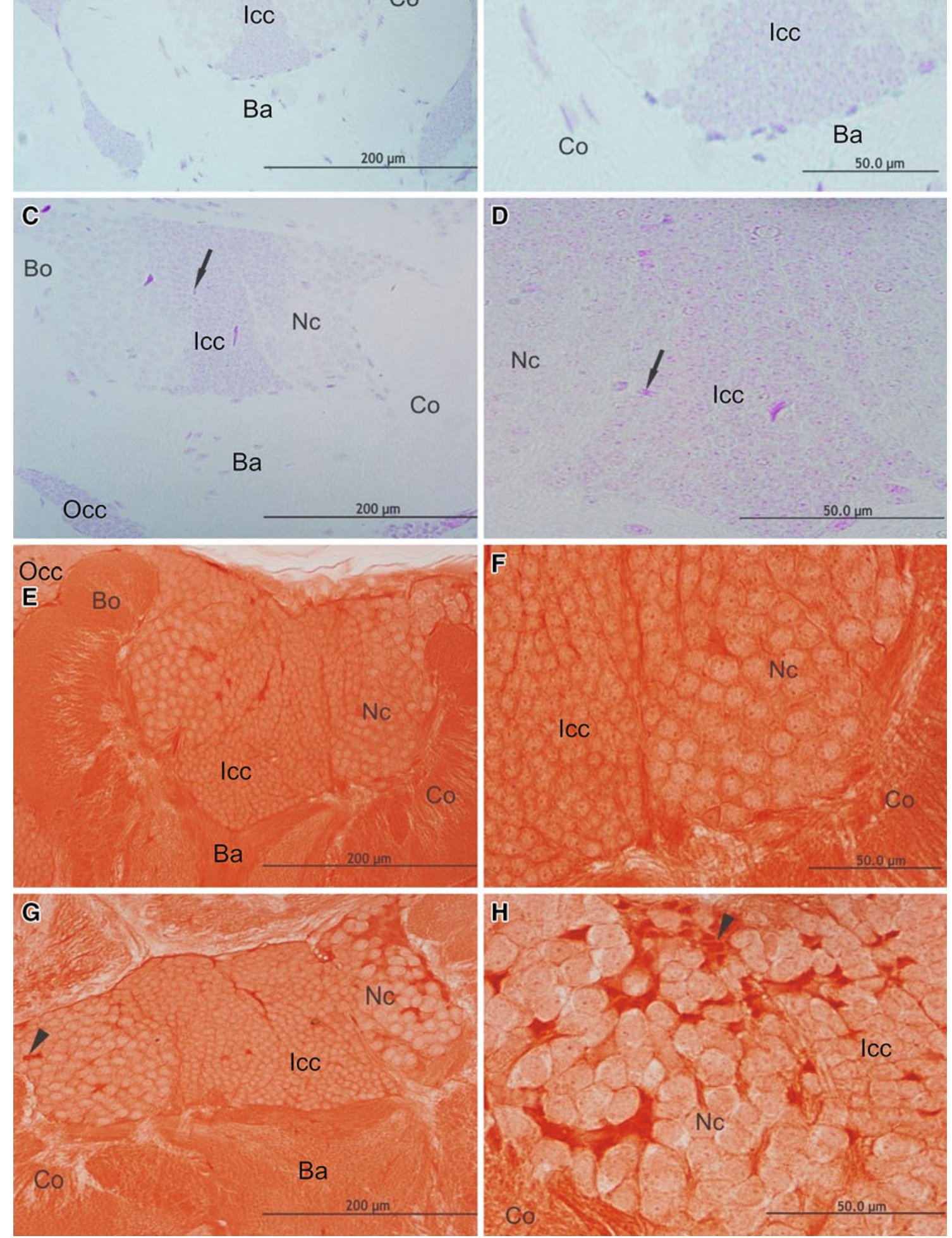
4Fig. 2 Images of Feulgen reaction and Xylidine Ponceau staining of mushroom bodies of newly emerged workers of Africanized $A$. mellifera with or without exposure to imidacloprid. a, b General and magnified views of mushroom bodies from the control group for 3 days, submitted to Fuelgen reaction, showing nuclei weakly stained with chromatin decondensed. c, d General view and detail of mushroom bodies of bees exposed to $\mathrm{LD}_{50 / 10}$ for 10 days submitted to Fuelgen reaction. Note the presence of intensely stained nuclei (arrows). e, f General view and detail of mushroom bodies from control group for 5 days submmited to Xylidine Ponceau stain. $\mathbf{g}$, $\mathbf{h}$ General view and detail of mushroom bodies from bees exposed to $\mathrm{LD}_{50} / 10$ for 10 days and exposed to $\mathrm{LD}_{50 / 50}$ for 3 and 7 days, respectively. Observed increased intensity of staining of some cells (arrowheads). Ba basal ring, Bo border, Co collar, Occ outer compact cells, Icc inner compact cells, Nc noncompact cells

which occurs during the process of cell death (Willye 1981; Häcker 2000; Silva-Zacarin et al. 2008).

During cell death by apoptosis, homeostasis is maintained by controlling the number of antiapoptotic and proapoptotic proteins. Stimuli, such as DNA damage, can evoke increased expression of proapoptotic proteins, and this imbalance can induce apoptosis (Petros et al. 2004). In the present study, the technique used to detect total protein (Xylidine Ponceau staining) showed more intense staining in cells in mushroom bodies and optic lobes of bees exposed to imidacloprid compared with tissues from control bees. This result may indicate the occurrence of increased protein synthesis in imidacloprid-treated bees. This increase may reflect the activation of signaling pathways that participate in cell death, or it could result from cell condensation.

Morphological and histochemical analysis revealed the presence of condensed cells, cells containing nuclei with condensed chromatin, and cells in which there was increased protein synthesis; these characteristics are typically observed in cells undergoing cell death. Cells with these characteristics were present in mushroom bodies of bees exposed to imidacloprid concentrations of $\mathrm{LD}_{50 / 10}$ for $\geq 3$ days, in optic lobes of bees exposed to imidacloprid concentrations of $\mathrm{LD}_{50 / 10}$ for all exposure times tested, and

Table 2 Summary of morphological, histochemical, and immunohistochemical analyses of optical lobes in A. meliffera exposed to sublethal doses of imidacloprid

\begin{tabular}{|c|c|c|c|c|c|}
\hline Treatment & Days & $\begin{array}{l}\text { H\&E staining } \\
\text { Condensed } \\
\text { cells }\end{array}$ & $\begin{array}{l}\text { Fuelgen reaction } \\
\text { Nuclei with compaction } \\
\text { of chromatin }\end{array}$ & $\begin{array}{l}\text { Xylidine Ponceau staining } \\
\text { Increase in the intensity } \\
\text { of staining }\end{array}$ & $\begin{array}{l}\text { TUNEL reaction } \\
\text { Nuclei positive to } \\
\text { TUNEL reaction }\end{array}$ \\
\hline \multirow{5}{*}{ Control without solvent } & 1 & - & - & - & - \\
\hline & 3 & - & - & - & - \\
\hline & 5 & - & - & - & - \\
\hline & 7 & - & - & - & - \\
\hline & 10 & - & - & - & - \\
\hline \multirow[t]{5}{*}{ Control with solvent } & 1 & - & - & - & - \\
\hline & 3 & - & - & - & - \\
\hline & 5 & - & - & - & - \\
\hline & 7 & - & - & - & - \\
\hline & 10 & - & - & - & - \\
\hline \multirow[t]{5}{*}{$\mathrm{LD}_{50 / 100}$} & 1 & - & - & - & + \\
\hline & 3 & - & - & - & + \\
\hline & 5 & + & + & + & + \\
\hline & 7 & + & + & + & + \\
\hline & 10 & + & + & + & + \\
\hline \multirow[t]{5}{*}{$\mathrm{LD}_{50 / 50}$} & 1 & - & - & - & + \\
\hline & 3 & - & - & - & + \\
\hline & 5 & + & + & + & + \\
\hline & 7 & + & + & + & + \\
\hline & 10 & + & + & + & + \\
\hline \multirow[t]{5}{*}{$\mathrm{LD}_{50 / 10}$} & 1 & + & + & + & + \\
\hline & 3 & + & + & + & + \\
\hline & 5 & + & + & + & + \\
\hline & 7 & + & + & + & + \\
\hline & 10 & + & + & + & + \\
\hline
\end{tabular}

+ presence of alteration, ++ alteration moderately present, +++ alteration extremely present, - alteration absent, $L_{50}$ lethal dose 

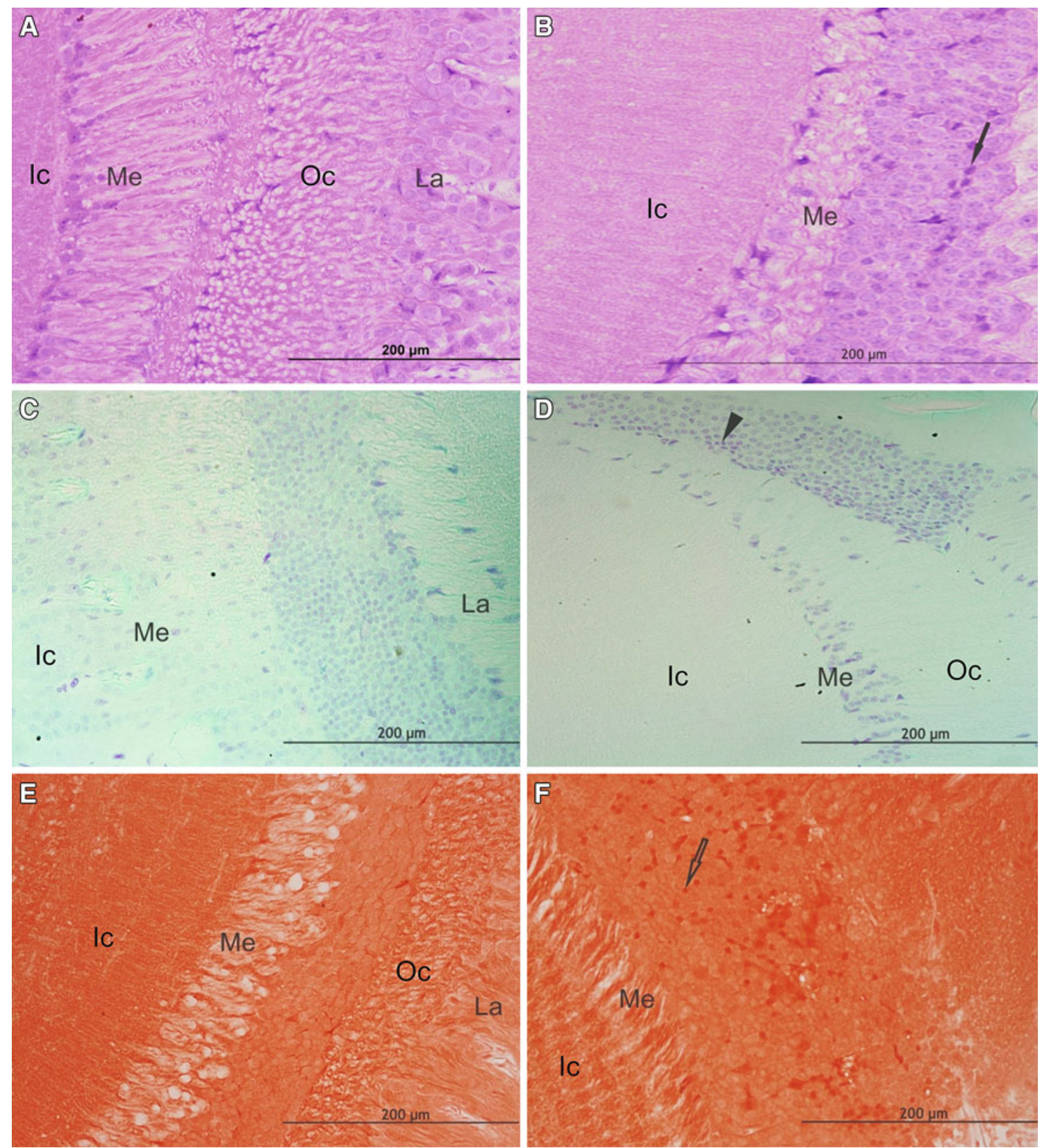

Fig. 3 Images of optical lobes of newly emerged workers of Africanized A. mellifera with or without exposure to imidacloprid. a Optical lobes stained with H\&E from control group for 5 days without morphological alteration. b Optical lobes stained with H\&E from bees exposed to $\mathrm{LD}_{50 / 50}$ for 7 days showing intensely stained cells (arrow). c Optical lobes submitted to Fuelgen reaction from control group for 10 days without histochemical alteration. d Optical

in optic lobes of bees exposed to imidacloprid concentrations of $\mathrm{LD}_{50 / 100}$ and $\mathrm{LD}_{50 / 50}$ for 5,7 , or 10 days. In contrast, TUNEL reaction produced positive nuclei in mushroom bodies of bees exposed to $\mathrm{LD}_{50 / 10}$ and optic lobes of bees exposed to all doses of imidacloprid for all exposure times tested. Such differences may reflect differences in the stage of cell death. TUNEL reaction may detect positive nuclei when cells are in the initial stages of

lobes submitted to Fuelgen reaction from bee exposed to $\mathrm{LD}_{50 / 100}$ for 10 days. Note the presence of intensely stained nuclei (arrowhead). e Optic lobes submitted to Xylidine Ponceau stain from control group for 5 days without alteration. $\mathbf{f}$ Optic lobes submitted to Xylidine Ponceau stain of bee exposed to $\mathrm{LD}_{50 / 10}$ for 7 days. Note the intensely stained cells (arrow outline). La lamina, Me medulla, Oc outer chiasmata, Ic inner chiasmata

cell death. In contrast, cell and chromatin condensation, which were detected using morphological and histochemical techniques, may occur during the final stages of cell death. Alternatively, cell and chromatin condensation might reflect the presence of autophagic or apoptotic cells, in which endonucleases do not cause DNA fragmentation.

A comparison of the results derived from the imidacloprid treatment groups indicates that optic lobes are more 

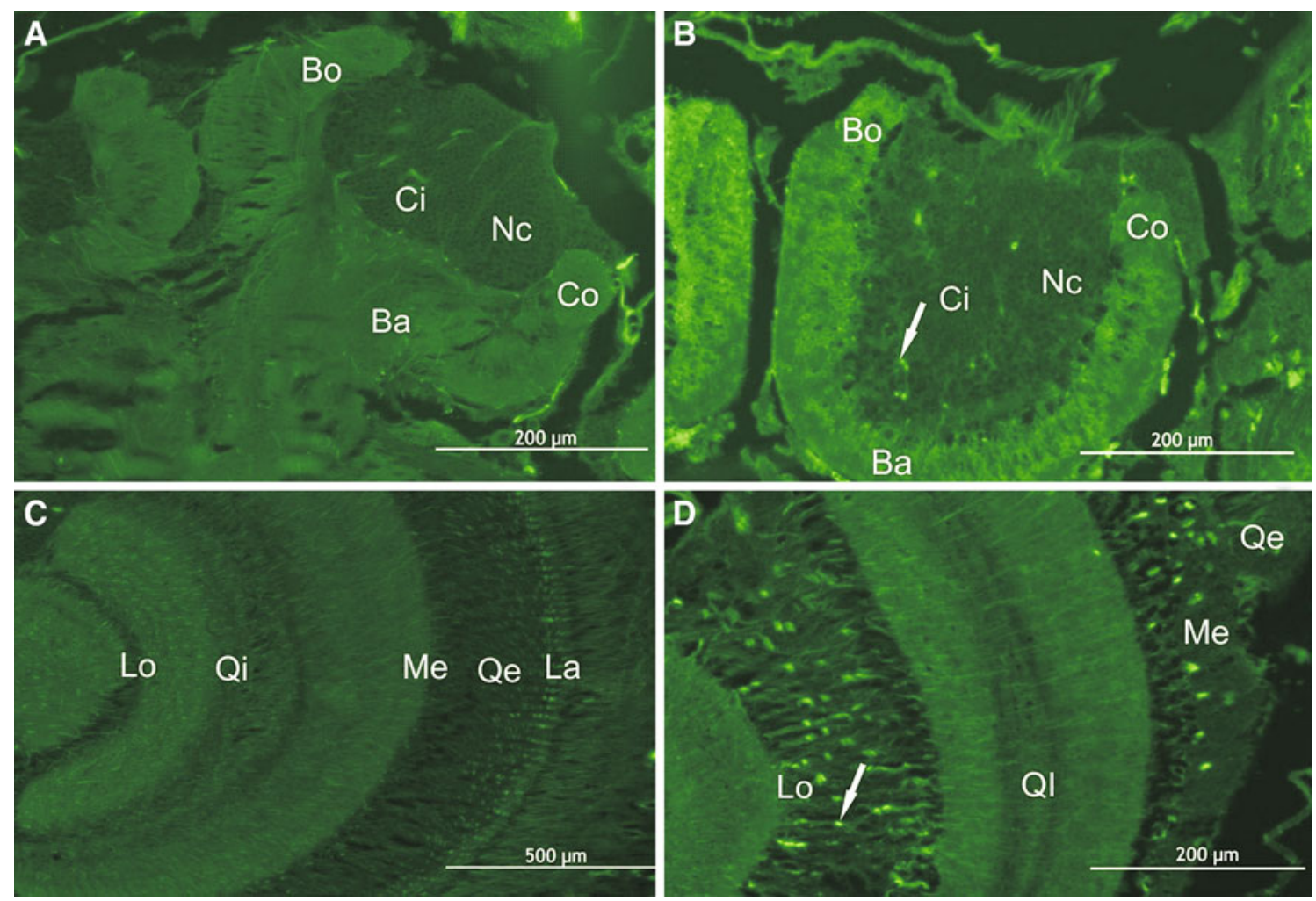

Fig. 4 Images of the cerebral structure of newly emerged workers of Africanized A. mellifera with or without exposure to imidacloprid submitted to TUNEL reaction. a Mushroom bodies from control group for 7 days with no positive nuclei. b Mushroom bodies of $\mathrm{LD}_{50 /}$ 10 group for 1 day with positive nuclei in response to TUNEL reaction. c Optical lobes of the control group for 5 days with no

sensitive to insecticide relative to the other cerebral structures analyzed. Changes in optic lobes were observed at all doses of imidacloprid for all exposure times tested. In contrast, changes observed in mushroom bodies were only observed in bees treated with imidacloprid concentrations of $\mathrm{LD}_{50 / 10}$.

The visual system of an adult insect consists of the retina (the eye itself), which contains photoreceptor cells, and the optic lobes, which comprise three layers: the lamina, the medulla, and the lobula. The retinal cells form a highly ordered arrangement of repeated units of ommatidia (Ready et al. 1976). Within the ommatidium, each retinal unit (consisting of eight or nine photo-sensing cells) projects axonal beams toward the optic lobes to form synapses in the lamina and possibly in the medulla. Neurons from the lamina extend axons into the medulla and then to the lobula (Horridge 1965). Thus, cell death in optic lobes can result in fewer neurons and consequently decrease the number of synapses between this structure and the compound eyes. Therefore, the structural changes induced in optic lobes of bees may lead to problems with the visual acuity and consequently may negatively impact foraging worker bees.

positive nuclei. d Optical lobes of bees exposed to $\mathrm{LD}_{50 / 10}$ by 7 and 3 days, respectively. Note the presence positive nuclei in response to TUNEL reaction (arrow). Br basal ring; Bo border, Co collar, Occ outer compact cells, Icc inner compact cells, $N c$ non compact cells, $L a$ lamina, $M e$ medulla, $O c$ outer chiasmata, $I c$ inner chiasmata

Bortolotti et al. (2003) evaluated the effects of sublethal doses of imidacloprid on the foraging behavior and return to the colony of A. mellifera. Bees from the control groups returned to the feeder within $5 \mathrm{~h}$. Bees fed syrup containing $100 \mathrm{ppb}$ of insecticide returned to the feeder after $24 \mathrm{~h}$. Bees exposed to 500 and $1,000 \mathrm{ppb}$ of insecticide did not return to the colony or to the feeder. In these studies, it is possible that exposure of bees to imidacloprid caused cell death in the optic lobes, as observed in the present study, which may have impaired their visual acuity.

Our study also focused on mushroom bodies because this brain structure is involved in learning and memory in bees (Daly et al. 1998; Cruz-Landim 2009). In mushroom bodies of bees exposed to imidacloprid concentrations of $\mathrm{LD}_{50 / 10}$ for 3, 5, 7 and 10 days, nuclei containing condensed chromatin were detected. In mushroom bodies of bees exposed to imidacloprid for longer periods of time, swelling of cell bodies was also observed. Therefore, we conclude that the concentration of insecticide to which the bees were exposed is a more important factor in insecticide-induced damage to the brain than duration of insecticide exposure. 
Because of the contribution of mushroom bodies to learning and memory processes in bees, damage to these structures can cause disorientation and impair their foraging activity. As a result, the function of the entire colony can be affected.

The results of this study show that imidacloprid causes morphological, histochemical, and immunocytochemical alterations in optic lobes and mushroom bodies of bees. Therefore, sublethal doses of this insecticide can negatively affect honeybee physiology, possibly by disrupting their visual system and impairing their learning capacity (El Hassani et al. 2008). These changes could lead to abnormal behavior and possibly to the death of the affected bees.

Acknowledgments The authors thank the Fundação de Amparo a Pesquisa do Estado de São Paulo/FAPESP for the financial support (Grants No. 2008/05018-7 and 2006/57122-7) and the Brazilian Council for Scientific and Technological Development/CNPq. We thank Bibiana Monson de Souza for critical review of the manuscript.

\section{References}

Bicker G (1999) Histochemistry of classical neurotransmitters in antennal lobes and mushroom bodies of the honeybee. Microsc Res Tech 45:174-183

Bortolotti L, Montanari R, Marcelino J, Medrzycki P, Maini S, Porrini C (2003) Effects of sub-lethal imidacloprid doses on the homing rate and foraging activity of honey bees. Bull Insectology $56: 63-67$

Bowen ID, Bowen SM, Jones AH (1998) Mitosis and apoptosis: matters of life and death. Chapman \& Hall, New York

Brasil (2001) Ministério da Agricultura, Pecuária e Abastecimento. http://www.agricultura.gov.br. Accessed 7 Jan 72010

Buckingham SD, Lapied B, Corrong HLE, Grolleau F, Sattelle DB (1997) Imidacloprid actions on insect neuronal acetylcholine receptors. J Exp Biol 200:2685-2692

Croft BA (1990) Arthropod biological control agents and pesticides. Wiley, New York

Cruz-Landim C (2009) Abelhas: morfologia e função de sistemas. Unesp, São Paulo

Daly HV, Doyen JT, Purcell AH (1998) Introduction to insect biology and diversity. Oxford University Press, New York

Decourtye A, Lacassie E, Pham-Delègue M (2003) Learning performances of honeybees (Apis mellifera L) are differentially affected by imidacloprid according to the season. Pest Manag Sci 59(3):269-278

Decourtye A, Devillers J, Cluseau S, Charreton M, Pham-Delegue MH (2004) Effects of imidacloprid and deltamethrin on associative learning in honeybees under semi-field and laboratory conditions. Ecotoxicol Environ Saf 57:410-419

Desneux N, Decourtye A, Delpuech JM (2007) The sublethal effects of pesticides on beneficial arthropods. Annu Rev Entomol 52:106-2007

El Hassani AK, Dacher M, Gary V, Lambin M, Gauthier M, Armengaud C (2008) Effects of sublethal doses of acetamiprid and thiamethoxam on the behavior of the honeybee (Apis mellifera). Arch Environ Contam Toxicol 54:653-661

Faucon J, Aurières C, Drajnudel P, Mathieu L, Ribière M, Martel A et al (2005) Experimental study on the toxicity of imidaclopride given syrup to honey bee (Apis mellifera) colonies. Pest Manag Sci 61:111-125

Feulgen R, Rossenbeck H (1924) Mikroskopisch Chemischer Nachweis einer Nucleinsaure vom Typus der Thymonucleinsaure und Die Darauf Beruhend Elective Farbung von Zillkernen in Mikroskopischen Praparaten Hoppe-Seylers. Hoppe Seylers Z Physiol Chem 206:389-410

Gallai N, Salles J-M, Settele J, Vaissière BE (2009) Economic valuation of the vulnerability of world agriculture confronted with pollinator decline. Ecol Econ 68:810-821

Guez D, Suchail S, Gauthier M, Maleszka R, Belzunces LP (2001) Contrasting effects of imidaclopride on habituation in 7- and 8-day old honeybees (Apis mellifera). Neurobiol Learn Mem $76: 183-191$

Häcker G (2000) The morphology of apoptosis. Cell Tissue Res 301:5-17

Horridge GA (1965) Arthropoda: receptors for light and optic lobes. In: Bullock TH, Horridge GA (eds) Structure and function of the nervous system of invertebrates, vol 2. Freeman, San Francisco, pp 1063-1113

Junqueira LCU, Junqueira LMMS (1983) Técnicas básicas de citologia e histologia. Santos, São Paulo

Klein AM, Vaissière BE, Cane JH, Steffan-Dewenter I, Cunningham SA, Kremen C et al (2007) Importance of pollinators in changing landscapes for world crops. Proc R Soc Lond B Biol Sci 274:303-313

Malaspina O, Silva-Zacarin ECM (2006) Cell makers for ecotoxicological studies in target organs of bees. Braz J Morphol Sci 23:303-309

Medrzycki P, Montanari R, Bortolotti L, Sabatini AG, Maini S, Porrini C (2003) Effects of imidacloprid administered in sublethal doses on honey bee behaviour. Bull Insectology 56:59-62

Nauen R, Ebbinghaus-Kintscher U, Schmuck R (2001) Toxicity and nicotinic acetylcholine receptor interaction of imidacloprid and its metabolites in Apis mellifera (Hymenoptera: Apidae). Pest Manag Sci 57(7):577-586

Organisation for Economic Co-Operation and Development (1998) Guideline 214: guidelines for the testing of chemicals: Honeybees, Acute contact toxicity test. http://puck.sourceoecd.org/vl= $1619398 / \mathrm{cl}=20 / \mathrm{nw}=1 / \mathrm{rpsv} / \mathrm{ij} / \mathrm{oecdjournals} / 1607310 \mathrm{x} / \mathrm{v} 1 \mathrm{n} 2 / \mathrm{s} 15 /$ p1. Accessed 15 Feb 152010

Petros AM, Olejniczak ET, Fesik SW (2004) Structural biology of the Bcl-2 family of proteins. Biochim Biophys Acta 1644:83-94

Ready DF, Hanson TE, Benzer S (1976) Development of the Drosophila retina, a neurocrystalline lattice. Dev Biol 53:217240

Schmuck R (2004) Effects of a chronic dietary exposure of the honeybee Apis mellifera (Hymenoptera: Apidae) to imidaclopride. Arch Environ Contam Toxicol 47:471-478

Silva-Zacarin ECM, Taboga SR, Silva de Moraes RL (2008) Nuclear alterations associated to programmed cell death in larval salivary glands of Apis mellifera (Hymenoptera: Apidae). Micron 39: $117-127$

Suchail S, Guez D, Belzunces LP (2001) Discrepancy between acute and chronic toxicity induced by imidaclopride and its metabolites in Apis mellifera. Environ Toxicol Chem 20(11):2482-2486

Thompson HM (2003) Behavioural effects of pesticides in bees: their potential for use in risk assessment. Ecotoxicology 12:317-330

Willians CS (1995) Conserving Europe's bees: why all the buzz? Trends Ecol Evol 10:309-310

Willye AH (1981) Cell death: A new classification separating apoptosis from necrosis. In: Bowen ID, Lockshin RA (eds) Cell death in biology and pathology. Springer, New York 